\title{
Proangiogenic Collagen-Binding Glycan Therapeutic Promotes Endothelial Cell Angiogenesis
}

\author{
Tanaya Walimbe ${ }^{1}$, Tima Dehghani ${ }^{1}$, Alena Casella ${ }^{1}$, Jenny Lin ${ }^{2}$, Aijun Wang ${ }^{1,3}$, Alyssa \\ Panitch ${ }^{1,3 *}$ \\ ${ }^{1}$ Department of Biomedical Engineering, University of California, Davis, CA \\ ${ }^{2}$ Department of Surgery, Indiana University School of Medicine, Indianapolis, IN \\ ${ }^{3}$ Department of Surgery, University of California, Davis, CA
}

*To whom correspondence should be addressed:

Alyssa Panitch

Department of Biomedical Engineering

University of California, Davis

451 Health Sciences Drive, GBSF 2303

Davis, CA 95616

Email: apanitch@ucdavis.edu

Phone: +1 (765) 412-6082 


\section{Supplemental Data}

A

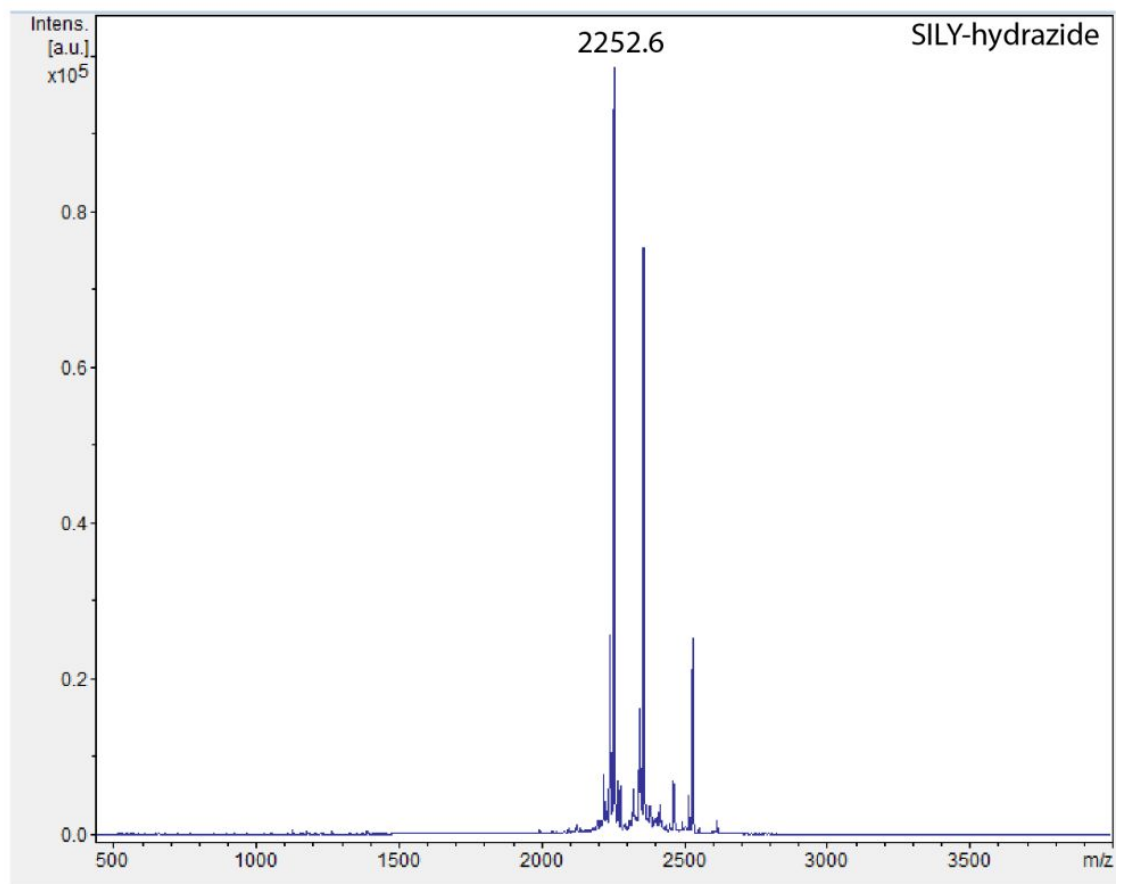

B

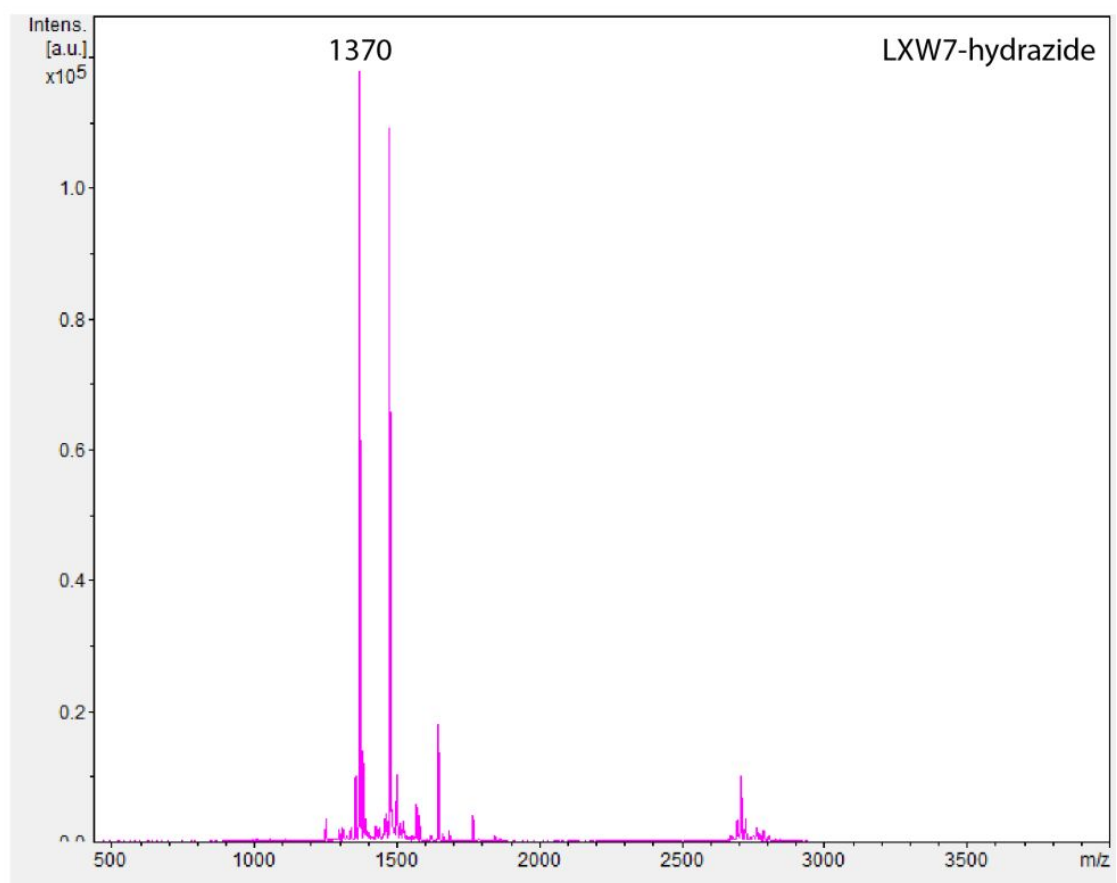

Figure S1: Matrix assisted laser desorption/ionization (MALDI) spectra for confirming successful synthesis of SILY-hydrazide (A) and LXW7hydrazide (B). SILY-hydrazide has a molecular weight of $2252.6 \mathrm{Da}$, and LXW7-hydrazide has a molecular weight of 1370 Da. The peaks $104 \mathrm{Da}$ higher result from hydrazide reactivity during MALDI. 


\section{Standard curves for peptide concentration}
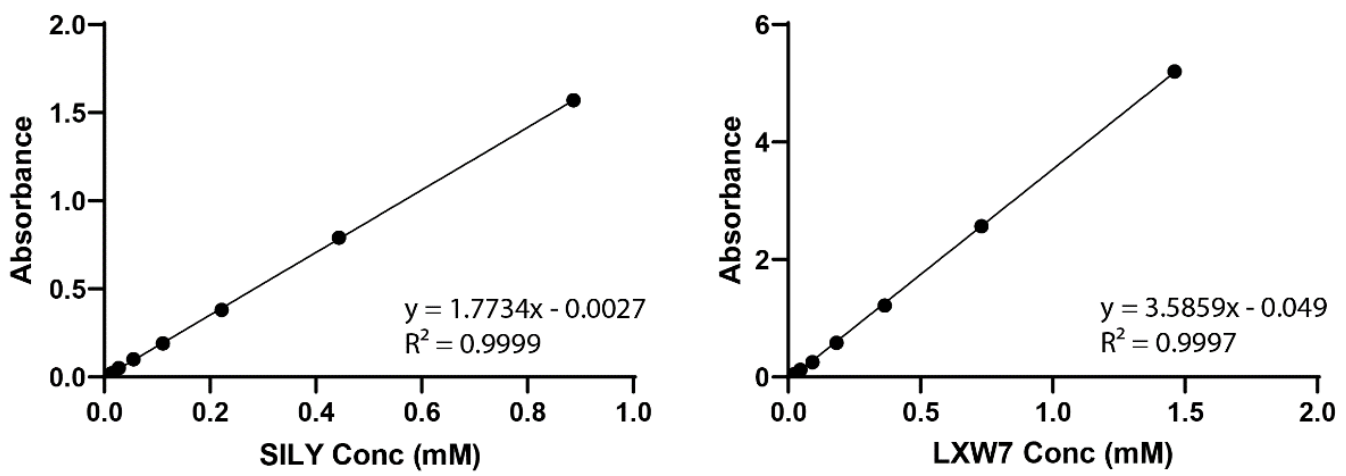

Figure S2: Standard curves for SILY-hydrazide and LXW7-hydrazide based on $280 \mathrm{~nm}$ absorbances using a nanodrop spectrophotometer. Amount of SILY and LXW7 conjugation to DS was extrapolated using these standard curves.

\begin{tabular}{|l|l|l|l|l|r|}
\hline $\begin{array}{l}214 \mathrm{~nm} \\
\text { calc }\end{array}$ & Peak & $\begin{array}{l}\text { Retention } \\
(\mathrm{ml})\end{array}$ & $\begin{array}{l}\text { Area } \\
\left(\mathrm{ml}{ }^{*} \mathrm{mAU}\right)\end{array}$ & Area \% & $\begin{array}{l}\text { Height } \\
(\mathrm{mAU})\end{array}$ \\
\cline { 2 - 6 } & Peak A & 13.216 & 1.101 & 0.12 & 1.987 \\
\hline
\end{tabular}

A SILY-hydrazide:

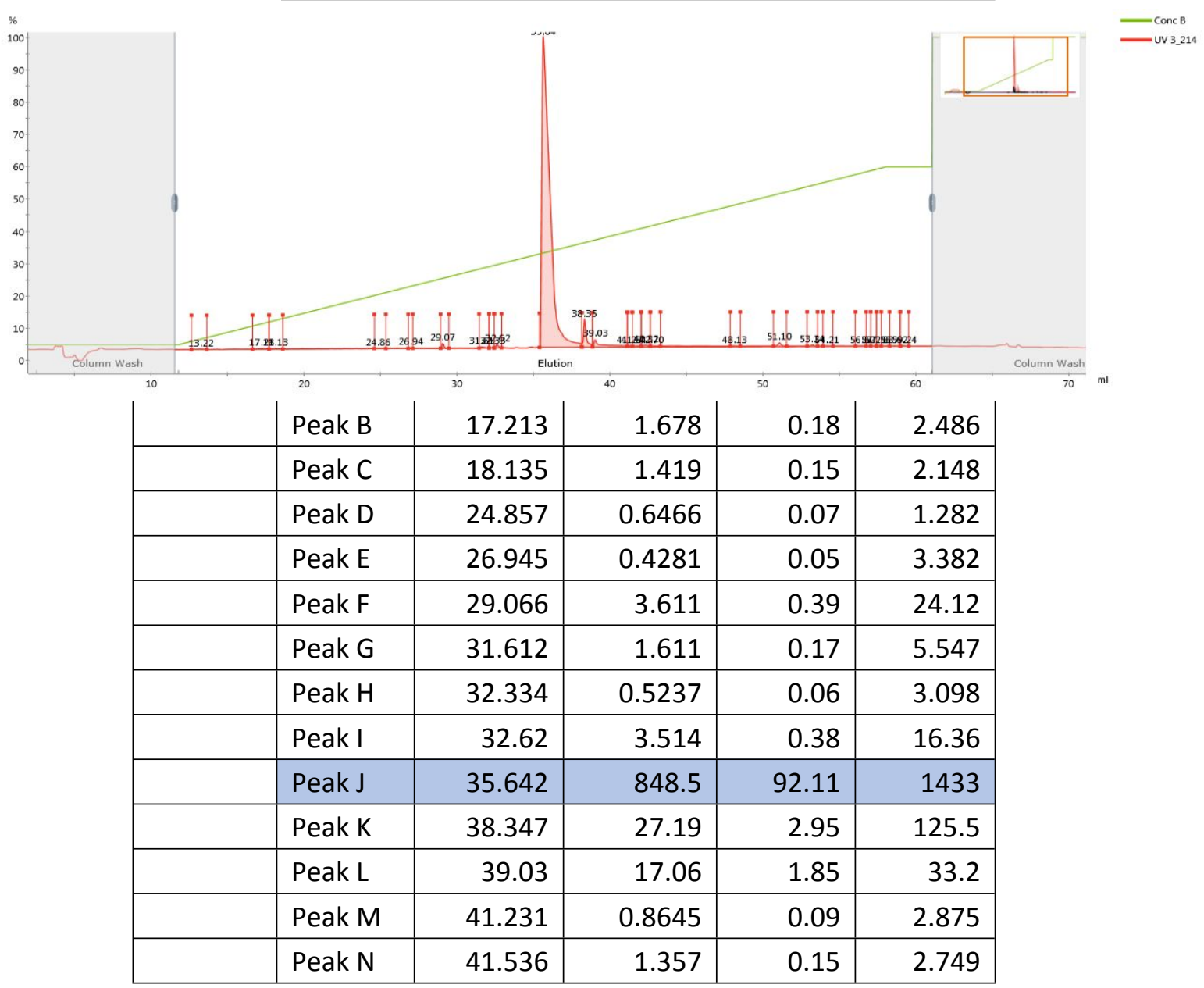




\begin{tabular}{|l|l|r|r|r|r|} 
& Peak O & 42.325 & 1.779 & 0.19 & 5.305 \\
\hline & Peak P & 42.696 & 0.8463 & 0.09 & 1.884 \\
\hline & Peak Q & 48.125 & 0.4509 & 0.05 & 1.429 \\
\hline & Peak R & 51.095 & 3.578 & 0.39 & 14.95 \\
\hline & Peak S & 53.243 & 1.269 & 0.14 & 6.223 \\
\hline & Peak T & 54.211 & 0.7583 & 0.08 & 1.891 \\
\hline & Peak U & 56.518 & 0.7631 & 0.08 & 1.391 \\
\hline & Peak V & 57.247 & 0.4382 & 0.05 & 1.361 \\
\hline & Peak W & 57.546 & 0.4176 & 0.05 & 1.609 \\
\hline & Peak X & 58.619 & 0.7965 & 0.09 & 1.848 \\
\hline & Peak Y & 59.243 & 0.5773 & 0.06 & 1.965 \\
\hline
\end{tabular}

B LXW7-hydrazide:

\begin{tabular}{|l|l|r|r|r|r|}
\hline $\begin{array}{l}214 \mathrm{~nm} \\
\text { calc }\end{array}$ & Peak & $\begin{array}{l}\text { Retention } \\
(\mathrm{ml})\end{array}$ & $\begin{array}{l}\text { Area } \\
\left(\mathrm{ml} \mathrm{m}^{*} \mathrm{mU}\right)\end{array}$ & Area \% & $\begin{array}{l}\text { Height } \\
(\mathrm{mAU})\end{array}$ \\
\hline & Peak A & 15.112 & 0.9666 & 0.06 & 1.891 \\
\hline
\end{tabular}

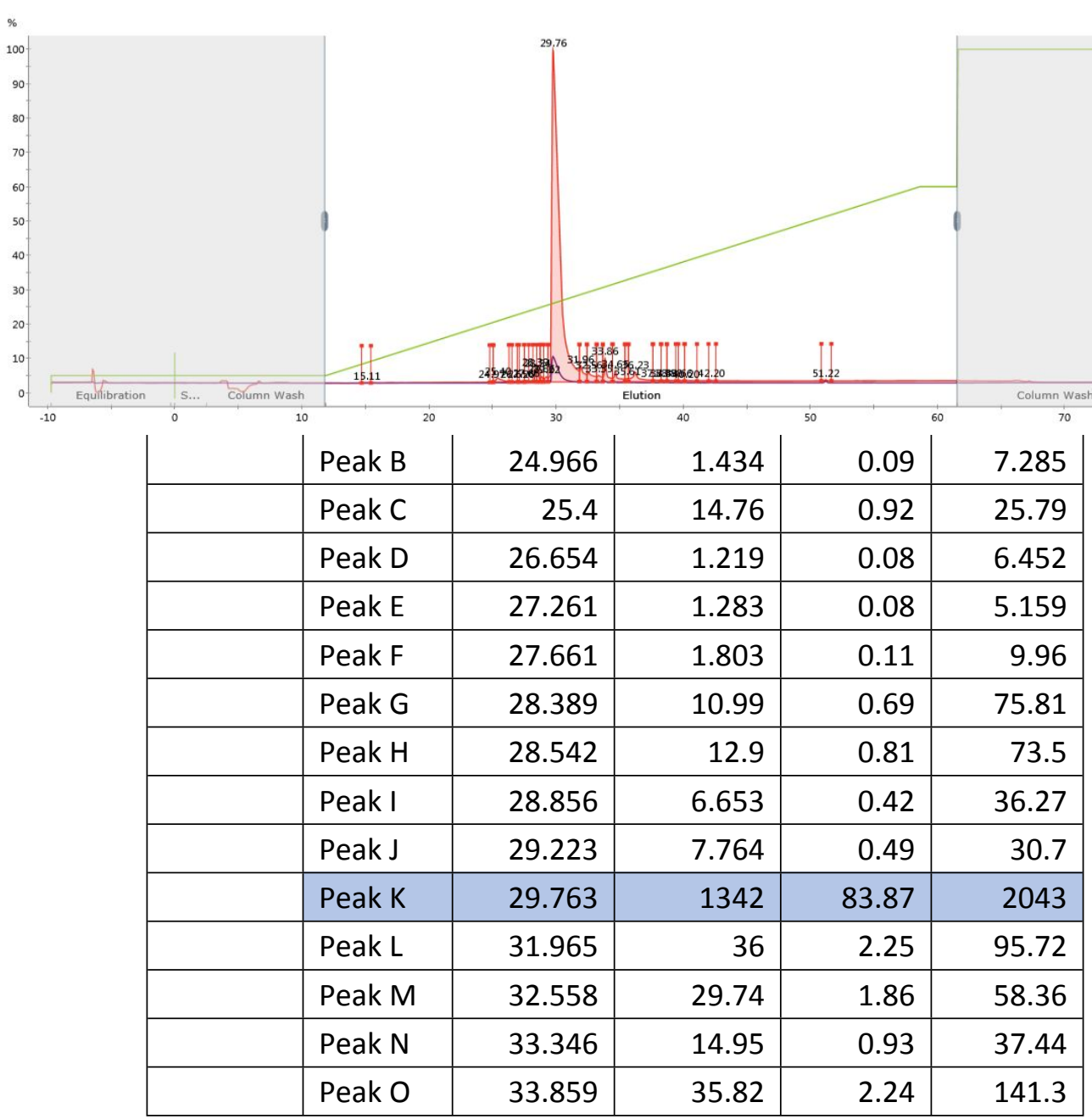




\begin{tabular}{|l|l|r|r|r|r|} 
& Peak P & 34.647 & 23.4 & 1.46 & 67.34 \\
\hline & Peak Q & 35.607 & 4.494 & 0.28 & 17.43 \\
\hline & Peak R & 36.228 & 35.52 & 2.22 & 60.22 \\
\hline & Peak S & 37.729 & 4.203 & 0.26 & 7.256 \\
\hline & Peak T & 38.429 & 2.559 & 0.16 & 6.017 \\
\hline & Peak U & 38.876 & 3.357 & 0.21 & 5.971 \\
\hline & Peak V & 39.664 & 1.784 & 0.11 & 3.957 \\
\hline & Peak W & 40.204 & 3.002 & 0.19 & 3.54 \\
\hline & Peak X & 42.199 & 1.681 & 0.11 & 4.399 \\
\hline & Peak Y & 51.219 & 1.777 & 0.11 & 7.191 \\
\hline
\end{tabular}

Figure S3: Purity of SILY-hydrazide and LXW7-hydrazide based on the area under the curve for $214 \mathrm{~nm}$ absorbances using a C18 analytical FPLC column. Purity of SILY was $92.11 \%$ and that of LXW7 was $83.87 \%$.

\section{Supplemental Methods - Gene Expression Studies: Cell Culture}

Chronopar fibrillar collagen type 1 (ChronoLog, Cat. 385) was diluted to $50 \mu \mathrm{g} / \mathrm{mL}$ in saline then added to the wells of a 96-well plate $(50 \mu \mathrm{L}$ per well). Plates were incubated for 1 hour in a cell culture incubator. Wells were washed $3 \mathrm{x}$ with DPBS before pre-treatment with molecule variants. Fifty $\mu \mathrm{L}$ of DPBS, DS6, 2LDS6, 4LDS6, or 6LDS6 (each at $10 \mu \mathrm{M}$ in DPBS) were added to individual wells in triplicate and incubated for 1 hour. Meanwhile, HDMECs (p3-5) were dissociated from T75 tissue culture flasks using $2 \mathrm{~mL}$ Versene Solution (Gibco, Cat. 15040066). After incubating for 5 minutes, a cell scraper was used to fully dissociate cells from the bottom of the flask. Endothelial cell growth media MV2 (PromoCell, Cat. C-39221) was added to neutralize the Versene. Cells were pelleted at $200 \mathrm{x} g$ for 5 minutes and resuspended at 400,000 live cells $/ \mathrm{mL}$ in MV2 media; $50 \mu \mathrm{L}$ of the cell suspension was added to each well. After incubating for 4 and 24 hours, media was aspirated, and cells were lysed with Buffer RLT Plus RNAeasy Plus Lysis Buffer (Qiagen) containing $1 \mathrm{v} / \mathrm{v} \% \beta$-mercaptoethanol at room temperature for 5 minutes with orbital shaking (300 RPM). Cell lysates were collected and vortexed for 1 minute, then frozen at $-80^{\circ} \mathrm{C}$ until RNA isolation.

\section{qRT-PCR}

Total endothelial cell RNA was isolated using an RNeasy Plus Mini Kit (Qiagen, Cat. 74136) according to the manufacturer's instructions. RNA was concentrated in the final step by running RNA-containing elution through the column twice. RNA was quantified using a NanoDrop One ${ }^{\mathrm{C}}$ (Thermo). RNA samples were diluted to the same concentration $(2.8 \mathrm{ng} / \mu \mathrm{L})$ before being reverse transcribed with a High Capacity cDNA Reverse Transcription Kit (Thermo, Cat. 4368814) according to manufacturer's instructions. qPCR was performed using TaqMan Fast Advanced Master Mix and a QuantStudio 5 (Thermo). Probes included MKI67 (Hs01032443_m1), KDR 
(Hs00911700_m1), PTK2 (Hs01056457_m1), ITGAV (Hs00233808_m1), and ITGB3

(Hs01001469_m1). Samples were held at $50{ }^{\circ} \mathrm{C}$ for 2 minutes and activated at $95{ }^{\circ} \mathrm{C}$ for 2

minutes before being subjected to 40 cycles of denaturing at $95{ }^{\circ} \mathrm{C}$ for 1 second and annealing at $60{ }^{\circ} \mathrm{C}$ for 20 seconds. All genes were normalized to the housekeeping gene RPL13

(Hs00744303_s1). Relative gene expression to DS-SILY was calculated using the $2^{-\Delta \Delta C t}$ method.
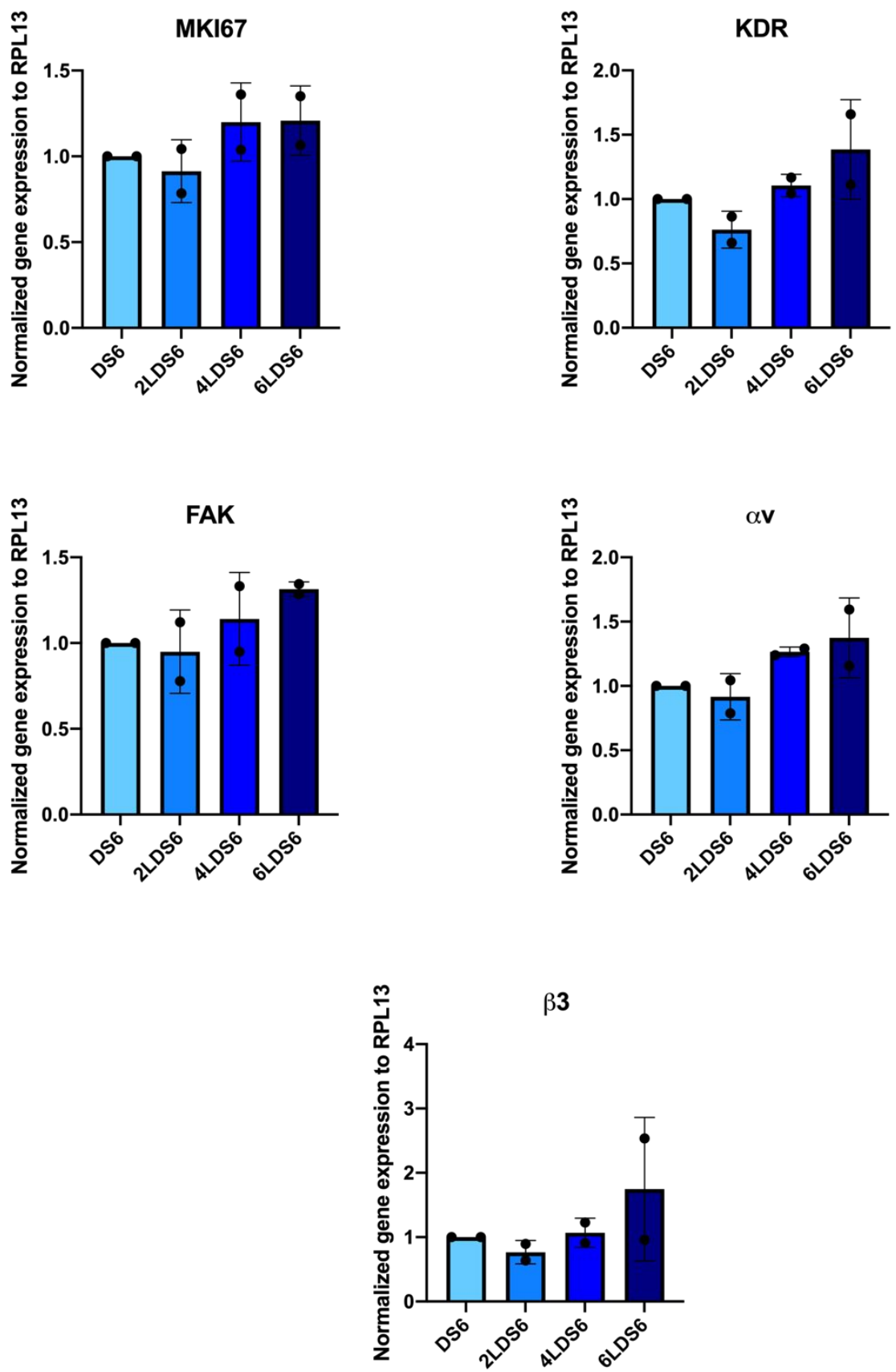
Figure S4: Gene expression of MKI67 (a proliferation marker), KDR (Kinase Insert Domain Receptor or VEGFR2), FAK (Focal Adhesion Kinase), integrin subunit $\alpha \mathrm{v}$ and integrin unit $\beta 3$ was tested $4 \mathrm{~h}$ after treatment with DS6 or the LDS variants. A trend towards increased gene expression is seen with increasing number of LXW7 peptides. 

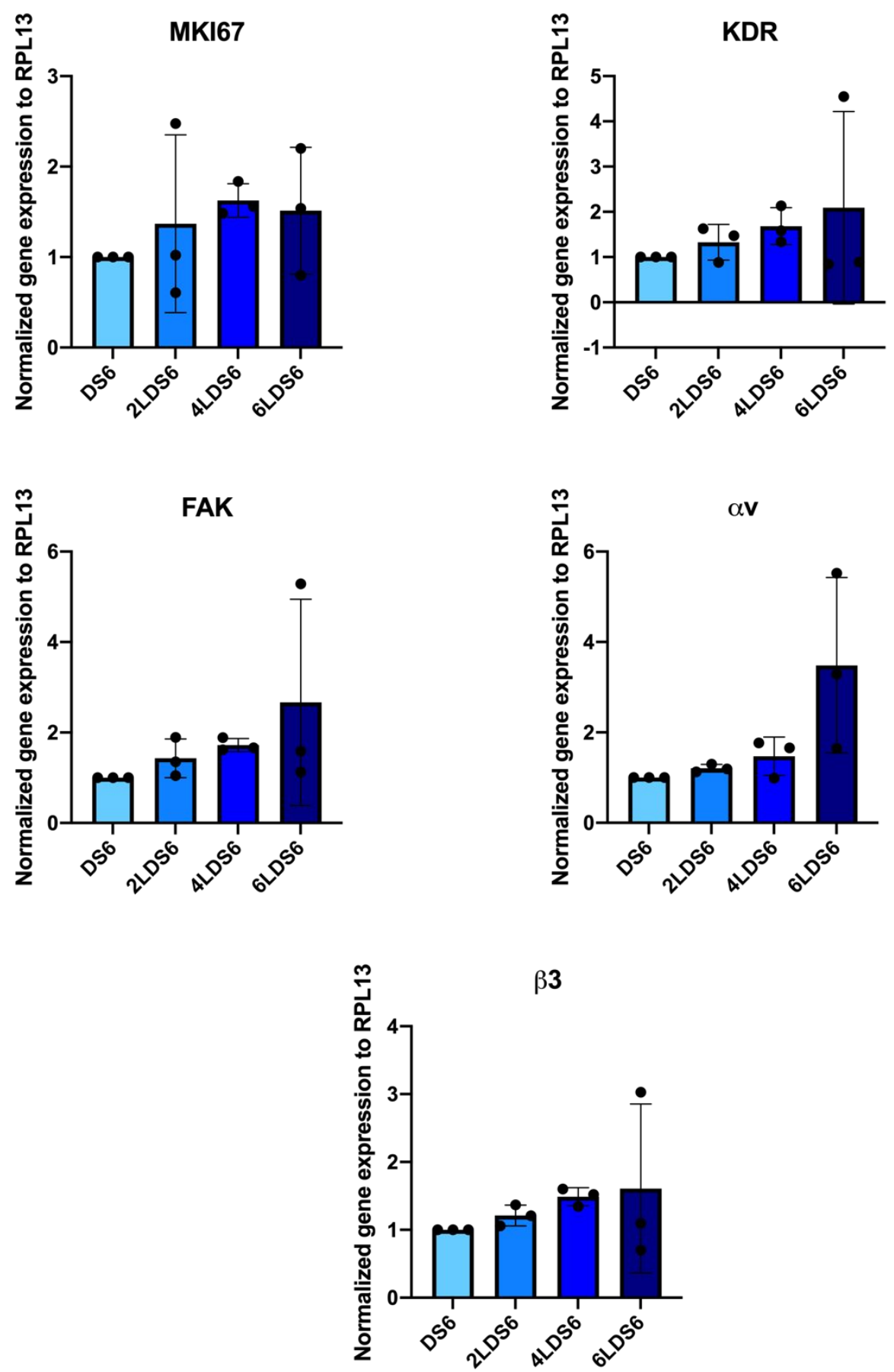

Figure S5: Gene expression of MKI67 (a proliferation marker), KDR (Kinase Insert Domain Receptor or VEGFR2), FAK (Focal Adhesion Kinase), integrin subunit $\alpha \mathrm{v}$ and integrin unit $\beta 3$ was tested $24 \mathrm{~h}$ after treatment with DS6 or the LDS variants. A trend towards increased gene expression is seen with increasing number of LXW7 peptides. 